\title{
THE REGULATION OF THE HUMAN SERUM-CHOLESTEROL LEVEL
}

\author{
By H. Gordon, M.D.(Cape Town) \\ Formerly Research Bursar, Clinical Nutrition Research Unit, Department of Medicine, University of Cape Town
}

Much of the present interest in cholesterol arises out of its occurrence in atheromatous lesions and the possibility that there may be a relationship between elevated serum-cholesterol levels and ischaemic heart disease. Cholesterol, however, is present in all animal tissues and it has considerable physiological, pathological and clinical importance. It is chemically related to several biologically significant substances including certain hormones (progesterone, aldosterone and cortisol), vitamin $\mathrm{D}$, bile acids and the benzpyrene group of carcinogenic hydrocarbons. It is an important physiological constituent of myelin and of the red-cell membrane, and it plays a major role in lipid-transport in vivo. Pathologically, it is prominent in gall-stones, in xanthomata and in some chronic granulomatous lesions. In clinical practice, low serum-cholesterol levels are sometimes found in chronic liver disease, in thyrotoxicosis and in anaemia; more constantly levels above the average are encountered in uncontrolled diabetes mellitus, the nephrotic syndrome, myxoedema, biliary obstruction, Cushing's syndrome, progeria and in some of the lipoidoses. Thus, there are many incentives for studying the factors which determine the level of an individual's serum-cholesterol and the deviations which occur from it.

\section{The Constancy of an Individual's Serum- Cholesterol Level}

When repeated determinations of an individual's serum-cholesterol level are made during the course of an ordinary day's activity and eating, no significant fluctuations are found (Boyd, 1935; Turner and Steiner, 1939; Keys, Anderson and Mickelsen, 1956). Several workers have shown, however, that when an individual's serum-cholesterol is repeatedly estimated at intervals of a week or more, quite substantial fluctuations often occur. Our own investigations confirm this (Gordon and Brock, 1958). Observations were made on a group of professional and business men eating ordinary diets and pursuing their usual activities; in each subject, the serum-cholesterol level was estimated on about 10 occasions at approximately weekly intervals. The mean intra-individual range (i.e. the difference .between each subject's highest and lowest readings) was $44.8 \mathrm{mg}$. per $100 \mathrm{ml}$. The pooled standard deviation of the serum-cholesterol level for the whole group was $14.7 \mathrm{mg}$. per $100 \mathrm{ml}$., indicating that when repeated estimations are made of an 'average' person's serum-cholesterol level, 95 per cent. of the values obtained will be within $29.4 \mathrm{mg}$. per roo $\mathrm{ml}$. of his mean value.

In some of our subjects, a second series of determinations was made under the same circum stances about six months after the first. Fluctuations of the same degree were noted during the second series as in the first; but in almost all cases it was found that the mean serum-cholesterol level during the second period was nearly the same as the mean level during the first period. This observation confirms what Sperry had noted in 1937 , i.e. that each individual has a ' characteristic' serum-cholesterol level but that fluctuations may occur about this level.

Hence it is urged that several readings of an individual's serum-cholesterol should be made before deciding whether his level is above, below, or within the average limits for his age, sex and race. Serial determinations are also necessary in studying the effect of dietary or other factors. In this respect, the 'internally controlled' trial with base-line observations both before and after the experimental period is particularly valuable. If such a procedure were more generally adopted, much of the present confusion and contradiction in cholesterol research might be avoided.

\section{Endogenous Factors and the Serum- Cholesterol Level Genetic}

Although the importance of hereditary influences in cases of essential hypercholesterol- 
aemia has been established for some time (Adlersberg, I95I; Wilkinson, Hand and Fliegelman, I948), their role in determining the serumcholesterol levels of the general population is less clearly understood. The serum cholesterol is affected by so many environmental factors, that the clear separation of the genetic influence from 'family habits' in related persons is extremely difficult. Recently, an ingenious study by Schaefer, Adlersberg and Steinberg (1958) has shed light on this problem. Data from a survey of serumcholesterol levels in 1,236 healthy persons, including 775 members of 201 families were analysed. There was no correlation between the serum-cholesterol levels of fathers and mothers but between father and child, mother and child and between siblings, the coefficient of correlation was highly significant; this may be interpreted as indicating the importance of the genotype in determining the serum-cholesterol level.

Further evidence of the role of genetic factors is derived from comparative studies of somatotypes: Gildea, Kahn and Man (1936) and Gertler and White (1954) found substantially lower serumcholesterol levels in those of ectomorphic (or leptosomic) habitus than in the endomorphs or mesomorphs. It is also probable that apart from any direct influence on the serum-cholesterol level, genetic factors may also account for the variability of individual responses to the same environmental factor.

\section{Age}

It is generally accepted that the serum-cholesterol level increases with age, but opinions differ about the age at which the peak level is reached. For men, it has been variously put at 33 years (Adlersberg et al., I957), 45 years (Lindholm, 1956), and 55 years (Keys et al., I950). An increasing serum-cholesterol level is not an inevitable manifestation of the ageing process. In Johannesburg, Bersohn and Wayburne (1956) found that while White and Bantu babies at birth had similar levels (means of $75 \mathrm{mg}$. per $100 \mathrm{ml}$. and $72 \mathrm{mg}$. per $100 \mathrm{ml}$. respectively), the White mothers had much higher levels than the Bantu mothers (means of $25^{8} \mathrm{mg}$. per $100 \mathrm{ml}$. and 190 mg. per $100 \mathrm{ml}$. respectively). Furthermore, Pomeranze et al. (1957) have shown that babies fed with an artificial soy-milk formula do not develop the rapid increase in serum-cholesterol level which usually occurs in the first few months of life. Clearly then, environmental and genetic factors may partly be responsible for the ageincrease in the serum-cholesterol level. The annual increment in an individual's mean serumcholesterol, however, is small and is not important in relation to the week-to-week and month-tomonth fluctuations about that mean.

Sex

The serum-cholesterol level in both men and women may be lowered by the administration of oestrogens (Eilert, I953; Barr, 1953). In women, cyclical fluctuations of the circulating-cholesterol level have been correlated with fluctuating oestrogenic activity (Oliver and Boyd, r953). Thus, in I2 healthy young women, marked falls occurred at the time of ovulation and just before menstruation, i.e. at the peaks of oestrogenic activity. In six healthy men, no cyclical changes were observed. It is presumably the activity of oestrogenic hormone which accounts for the fact that women often have lower serum-cholesterol levels than men during the reproductive years of their lives (Adlersberg et al., I957; Lawry et al., 1957).

\section{Exogenous Influences on the Serum- Cholesterol Level}

\section{Climate}

Geographical factors per se have little effect on the serum-cholesterol level. Thus, in the Cape Peninsula, White, Cape Coloured and Bantuo populations share the same climatic environment but their serum-cholesterol levels differ considerso ably (Bronte-Stewart et al., r955). The effect of seasonal changes on individual serum-cholesterol levels is unknown: Currie (1924), in Glasgow, claimed that the levels were higher in summer than in winter, but McEachern and Gilmour (1932), in Canada, denied this; neither of these two investigations was adequate, however, and conclusions cannot justifiably be drawn from them.

\section{Exercise}

The low serum-cholesterol levels of underprivileged races have been attributed by Mann et al. (1955) to the greater physical activity of these peoples; but from extensive epidemiological studies in Italy, Sweden, the United States of America, and South Africa, Keys and his associates (1956) concluded that the activity of work plays only a minor role in this respect. Only limited experimental studies have been carried out and it has been claimed that severe exercise may prevent the expected rise in the serum-cholesterol when either the dietary fat intake (Taylor, Anderson and Keys, 1957) or the dietary caloric intake (Mann et al., 1955) is increased. On the basis of this rather fragmentary evidence, it is tentatively concluded that varying physical activity may partly account for otherwise unexplained fluctuations in the serum-cholesterol level. 

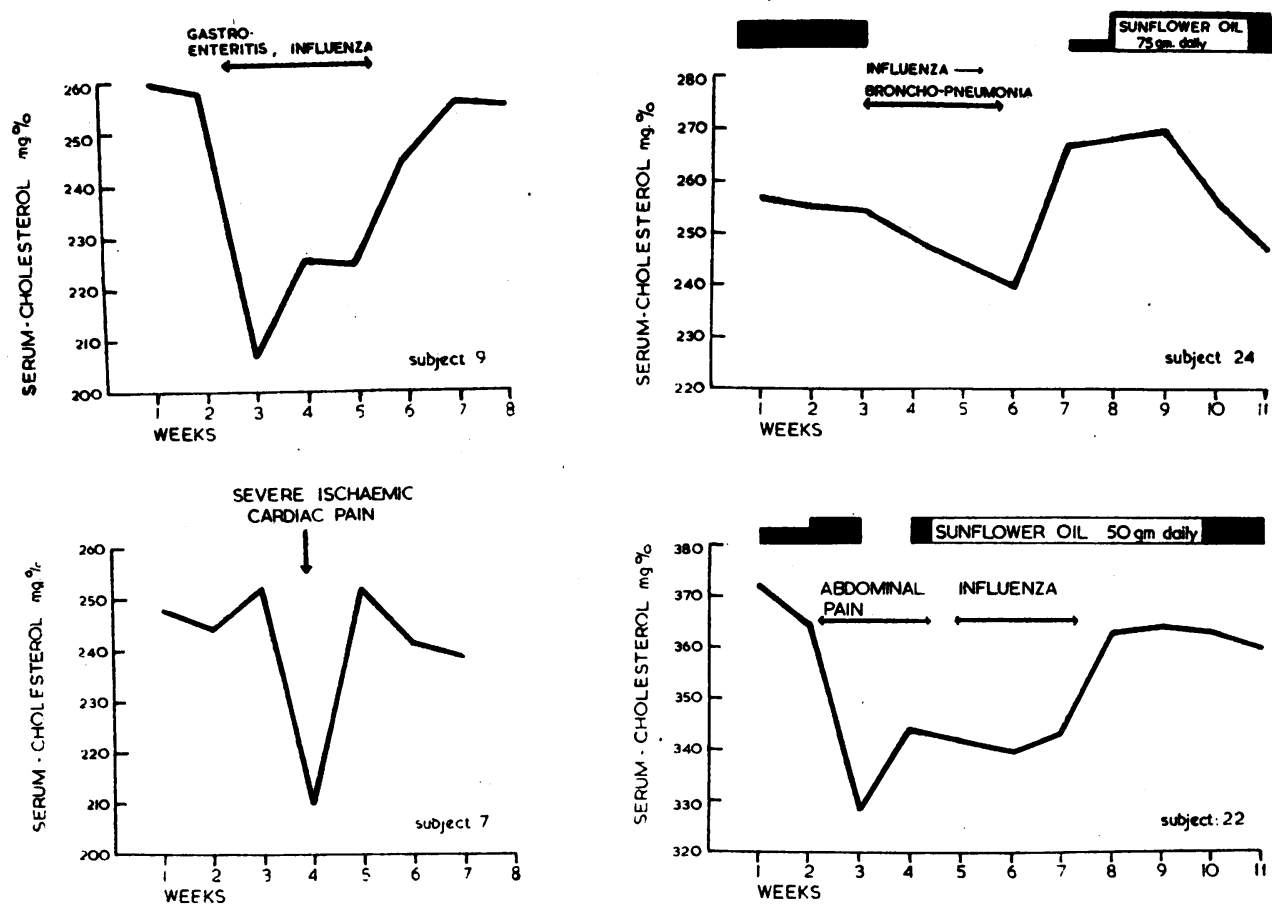

FIG. 1.-The week-to-week changes in the serum-cholesterol level accompanying infection, bowel disorders and coronary insufficiency in active men on ordinary diets, with and without fat supplements (from Gordon and Brock, 1958).

\section{Smoking}

The relation of cigarette-smoking and serumcholesterol levels has been studied in three surveys: by Gofman et al. (1955) in California, by BronteStewart (1956) in the Cape Peninsula and by Orma et al. (1958) in Finland. All three showed significantly, but not very strikingly, higher levels in smokers than in non-smokers. The reason for this difference is not clear: it may be due, as Bronte-Stewart has suggested, to the penchant of heavy smokers for more savoury and hence more fatty foods. Alternatively, there might be a genetic link between a tendency to higher serumcholesterol levels and penchant for smoking.

\section{Physical Stress}

The effects of acute physical stress have been studied under a variety of circumstances and the results have not been consistent; for example, brief immersion in very cold water produced an increase in the serum-cholesterol level (Ralli et al., 1956) but a ride on the human centrifuge did not (Beischer, 1955). More protracted physical stress, including surgical operations (Kyle et al., 1952), cardiac infarction (Biörck et al., 1957) and pneumonia (McQuarrie and Stoesser, 1932) usually reduce the serum-cholesterol level. In the children studied by McQuarrie and Stoesser, this reduction occurred when the diet was kept constant.

In adults on various dietary regimes, Groen et al. (1952) found that decreases in the serumcholesterol level occurred with upper-respiratorytract infections and with gastro-intestinal disorders. We have noted similar effects and in Fig. I some examples are shown of the changes in serum-cholesterol level accompanying influenza, pneumonia, gastro-enteritis and coronary insufficiency in subjects on their usual home diets with and without fat supplements. It must be emphasized, however, that both in our experience and from a perusal of the records published by Groen and his colleagues, it is not always possible to distinguish the changes due to physical stress from apparently ' spontaneous ' fluctuations in the serum-cholesterol level.

\section{Emotional Stress}

Attempts have been made to correlate fluctuations in the serum-cholesterol level with changes in the stress of living. Rosenman and Friedman (1957) observed a group of accountants and found that in the majority, the serum-cholesterol levels rose during the periods of increased pressure of work preceding business 'deadlines'; similarly, about half the medical students studied by Wertlake et al. (1958) had higher serum-choles- 
Table 1.-The Serum-Cholesterol Level (S.C.) of Men in the Fourth Decade in Relation to the Percentage of their Dietary Calories Derived from Fat. A Summary of Several Epidemiological Surveys

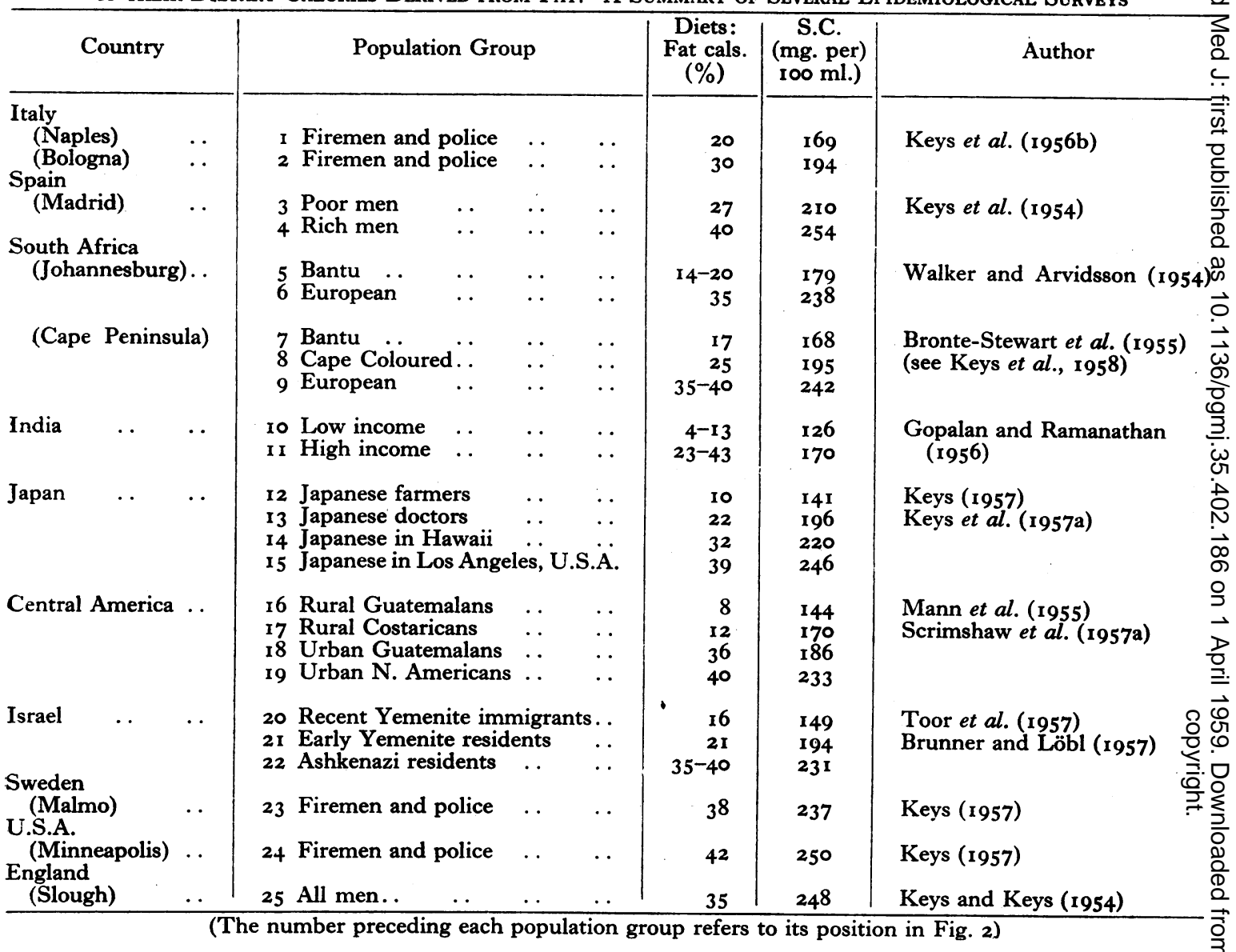

terol levels on the mornings of examinations than at less turbulent times. It will be realized that under such circumstances, changes in physical activity and in eating and smoking habits also occur, and until a procedure can be devised for studying the effects of sustained emotional stress in the absence of other variables, the case for this factor as a cholesterogenic agent will remain ' not proven.'

\section{Diet}

\section{(a) Cholesterol}

Much of the pioneer work on experimental atherosclerosis in rabbits was based on the results of feeding large amounts of cholesterol; this procedure regularly produced very considerable increases in the serum-cholesterol levels of these animals (Anitschkow, I933). Consequently, it was assumed that in the human, dietary cholesterol was similarly an important determinant of the serum-cholesterol level. In recent years, how- ever, several epidemiological and experimental studies in man have failed to justify this assumption. For example, Keys et al. (1956) in comparing two matched groups of middle-aged Minnesota 3 men, found that the serum-cholesterol levels of those habitually consuming a low-cholesterol diet (mean, 40r mg. daily) did not differ materially $\delta$ from those whose diet was relatively rich in 3 cholesterol (mean, r,oro mg. daily). A critical 은 experiment was carried out by Messinger et al. $\rightarrow$ (1950) when they showed that the addition of $30 \mathrm{~g}$. 을 of cholesterol daily to the diet of five men produced $\mathrm{N}$ only a very small rise in their serum-cholesterol levels. They also showed that the daily admin- 0 istration of $150 \mathrm{~g}$. of egg-yolk powder (containing $\mathrm{N}$ $3.75 \mathrm{~g}$. of cholesterol) produced a much greater increase in the serum-cholesterol level than ${ }_{5} 5$ to 0 $30 \mathrm{~g}$. of crystalline cholesterol: clearly, the egg cholesterol was not responsible for the increased ? serum-cholesterol level. These observations have been confirmed by several workers, and there is little doubt that, in man, the serum-cholesterol 


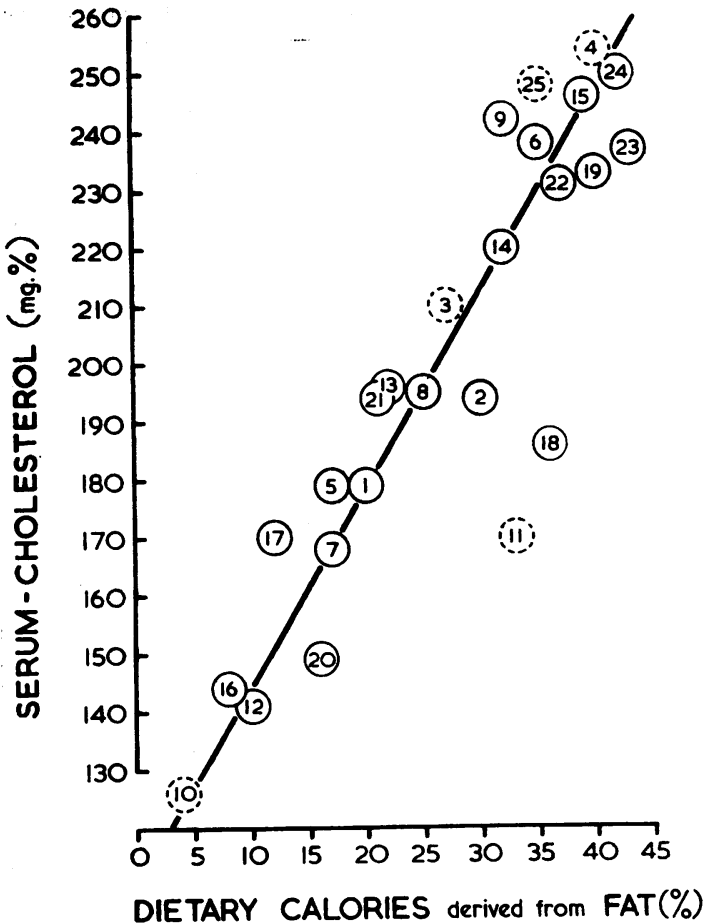

Fig. 2.-The relationship between the dietary fatcalorie ratio and the serum-cholesterol level in 24 population groups. (The data from which this graph was constructed are tabulated in Table I, and the numbers refer to the population groups listed there. All the serumcholesterol determinations except those in the broken circles were made by the method of Abell, Levy, Brodie and Kendall, 1952.)

level is largely independent of the dietary cholesterol intake.

\section{(b) Fat}

Total Dietary Fat: Since the end of the war, Keys and his associates at the University of Minnesota have been carrying out an extensive experimental and epidemiological study of the factors which regulate the human serum-cholesterol level. Their early findings led Keys (1952) to postulate that 'the major dietary factor which affects the serum-cholesterol level is the total fat, or the proportion of calories supplied by all fat metabolism.' World-wide epidemiological studies produced evidence which seemed to support this theory. Some of this evidence is presented in Table 1 and Fig. 2, in which it will be seen that in most population groups studied the relationship between the mean serum-cholesterol level and the dietary fat-calorie percentage is almost a linear one.

Low Fat Diets: Other investigations, however, failed to substantiate the pre-eminence of the total dietary fat. In the first instance, the effects of low-fat diets were often disappointing, very severe restriction of dietary fat being necessary to produce a moderate decrease in the serum-cholesterol level. For example, in a group of 13 men, Anderson and Keys (I953) achieved a fall of only $2 \mathrm{I} \mathrm{mg}$. per I00 $\mathrm{ml}$. by changing the fat content of the diet from 140 to 70 g. (i.e. from 37 per cent. to 18.5 per cent. fat-calories) for four weeks. In two large series of hypertensive cases treated with the ricediet (which is almost fat-free), Kempner (1949) and Starke (1950) reported decreases in the serumcholesterol level of $57 \mathrm{mg}$. per $100 \mathrm{ml}$. and $71 \mathrm{mg}$. per $100 \mathrm{ml}$. respectively. It must be noted that in these studies there was no control period and only single estimations of the serum-cholesterol were made before and after the use of the diet. On the other hand, Hatch et al. (1955) conducted a more elaborate investigation into this type of diet: several estimations were made of the serumcholesterol level both during a control period and during the various iso-caloric dietary regimes, all of which were carried out in 40 hypertensive subjects in hospital. Changing from $85 \mathrm{~g}$. of fat to $55 \mathrm{~g}$. and to 20 to $40 \mathrm{~g}$. of fat daily did not significantly decrease the serum-cholesterol level. Changing to the rice diet ( $3 \mathrm{~g}$. of fat) for 4 to 20 weeks produced a mean decrease of $33 \mathrm{mg}$. per $100 \mathrm{ml}$.

Vegetable Fats: The second discrepancy in the total dietary fat theory arose out of the observation that all fats did not influence the serum-cholesterol level in the same way. Thus, when Kinsell et al. (1952) fed a number of hospital patients with formula diets rich in vegetable fats, they observed a marked decrease in the serum-cholesterol level. At about the same time, in Holland, Groen et al. (r952) compared the effects of an ordinary diet with a high animal-fat diet and with a high vegetable-fat diet: the highest serum-cholesterol levels were found after the animal-fat diet, while they were lowest after the vegetable-fat diet. Similarly, it was observed that in vegetarians, despite an habitually high intake of vegetable fats, relatively low serum-cholesterol levels were maintained (Donath, et al., 1953; Hardinge and Stare, 1954). In an inter-racial survey in the Cape peninsula (Bronte-Stewart et al., 1955a) the serum-cholesterol trends were paralleled by trends in the animal-fat consumption. The vegetable-fat intake showed no correlation whatever. It appeared, therefore, that the cholesterogenic activity of fats was limited to those of animal origin and that vegetable fats either had no effect on the serum-cholesterol level or actually lowered it.

Unsaturated Fats: In 1955, in this Department, as a result of the above inter-racial survey a series of dietary experiments was begun in which the effects on the serum-cholesterol level of a large number of different fats were studied (BronteStewart et al., r955b; Bronte-Stewart et al., 1956). 


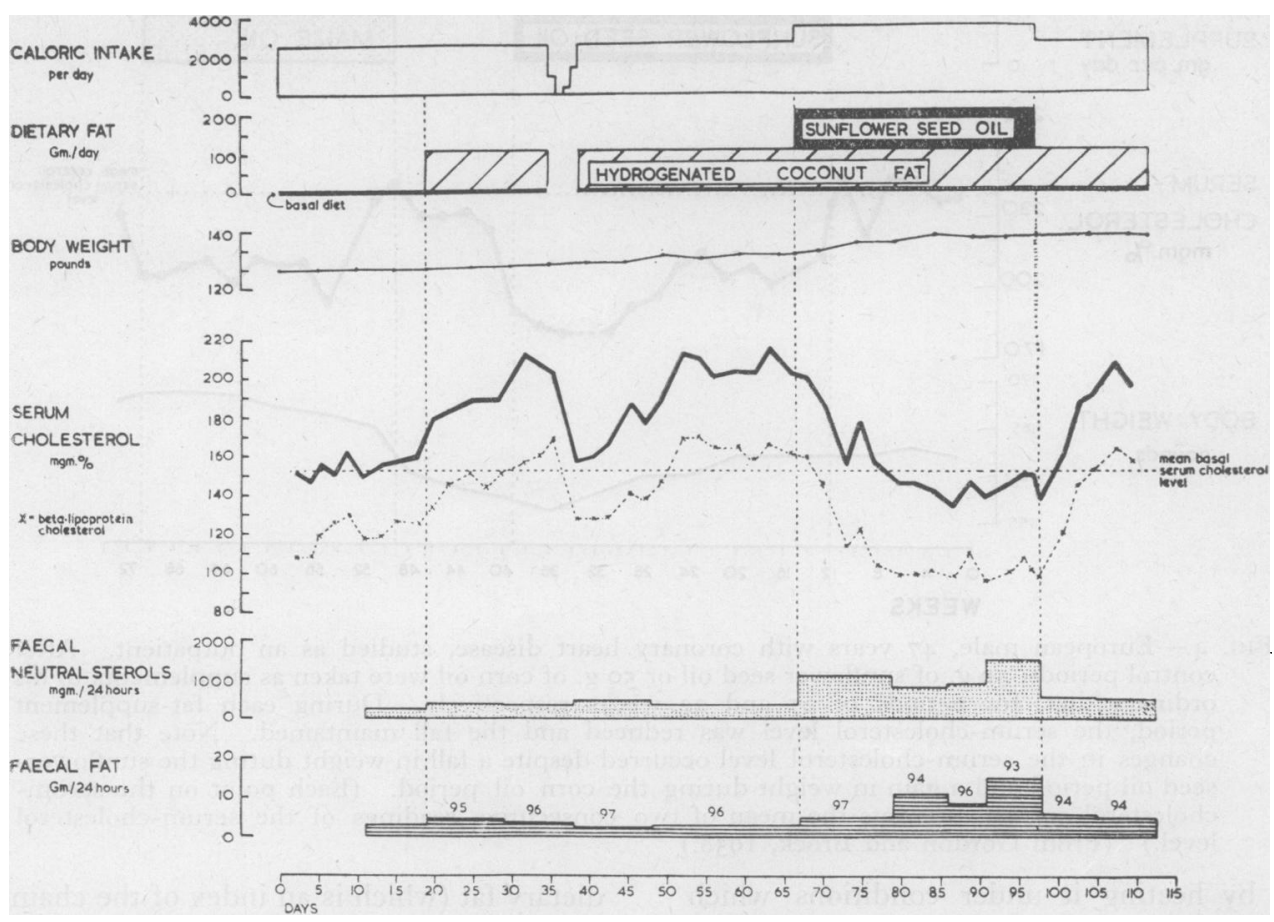

Fig. 3.- Normal Bantu male, 22 years old, studied in the metabolism ward. The introduction of $100 \mathrm{~g}$. of hydrogenated coconut fat daily into his diet raised this serum-cholesterol level. The further addition of $100 \mathrm{~g}$. of sunflower seed reduced the serum-cholesterol to basal level. On stopping the sunflower seed oil, the serum-cholesterol increased again.

Table 2.-Some Common Dietary Fats and their APPROXimate Iodine Values

\begin{tabular}{|c|c|c|c|c|c|}
\hline \multicolumn{5}{|c|}{ Fat } & \multirow{3}{*}{$\begin{array}{c}\begin{array}{c}\text { Iodine } \\
\text { value }\end{array} \\
\begin{array}{r}9 \\
38\end{array}\end{array}$} \\
\hline Coconut oil & . & $\cdots$ & .. & & \\
\hline Cocoa butter & . & . & .. & .. & \\
\hline Butter $\quad \ldots$ & & . & .. & .. & 40 \\
\hline Beef dripping ( $t$ & llow) & $\ldots$ & .. & .. & 45 \\
\hline Lard $\quad .$. & .. & .. & .. & .. & 60 \\
\hline Olive oil .. & $\cdots$ & $\therefore$ & $\therefore$ & $\begin{array}{l}. . \\
\end{array}$ & 90 \\
\hline Peanut oil ... & . & $\ldots$ & $\ddot{0} \quad$ & $\because$ & $\begin{array}{l}90 \\
98\end{array}$ \\
\hline Cottonseed oil & .. & $\therefore$ & $\therefore$ & .. & $\begin{array}{l}907 \\
107\end{array}$ \\
\hline Corn oil .. & .. & . & .. & $\because$ & 120 \\
\hline Whale oil ... & & .. & .. & .. & 120 \\
\hline Sunflower seed & & $\ldots$ & . & $\therefore$ & 135 \\
\hline Soya bean oil & . & $\cdots$ & $\because$ & 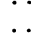 & $\begin{array}{l}135 \\
\times 38\end{array}$ \\
\hline Safflower oil & 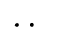 & & .. & .. & 145 \\
\hline Pilchard oil & . & $\therefore$ & $\therefore$ & . & 180 \\
\hline Sardine oil & & $\ldots$ & .. & .. & 188 \\
\hline
\end{tabular}

The initial experiments showed that the cholesterol decreasing effect of the unsaturated vegetable fat, sunflower-seed oil, was shared by the unsaturated marine-animal fats, pilchard oil and seal oil. But when the unsaturated vegetable fat, peanut oil was artificially saturated (hydrogenated) it tended to behave like the saturated animal fats in butter, tallow and beef, and increased the serum-cholesterol level. Finally, when the saturated and un- saturated components of fractionated sunflowerseed oil were fed separately, only the latter decreased the serum-cholesterol level, while the former increased it. Bronte-Stewart and his colleagues (1956) concluded from these observations that 'a possible common difference between animal fats and hydrogenated vegetable fat, on the one hand, and natural vegetable and marine oils, on the other ... is in some way connected with the proportion of highly unsaturated and saturated fatty acids in the fats concerned.'

A larger series of similar experiments was conducted by Ahrens et al. (1957) in New York, who concluded that 'the differences in (the serumlipid) levels are directly related to the degree of $N$ saturation of the glyceride fatty acids as easured by the iodine value of the fat.' Thus, the more saturated fats (i.e. those with the lowest iodine value) have the most potent cholesterogenic activity, while the more unsaturated the fat (i.e. the higher its iodine value) the greater is its cholesterol-decreasing effect. In Table 2 a number of common fats and their iodine values are listed.

Further studies in this Department (Gordon et al., 1957) have shown that the cholesteroldecreasing effect of sunflower-seed oil was not 


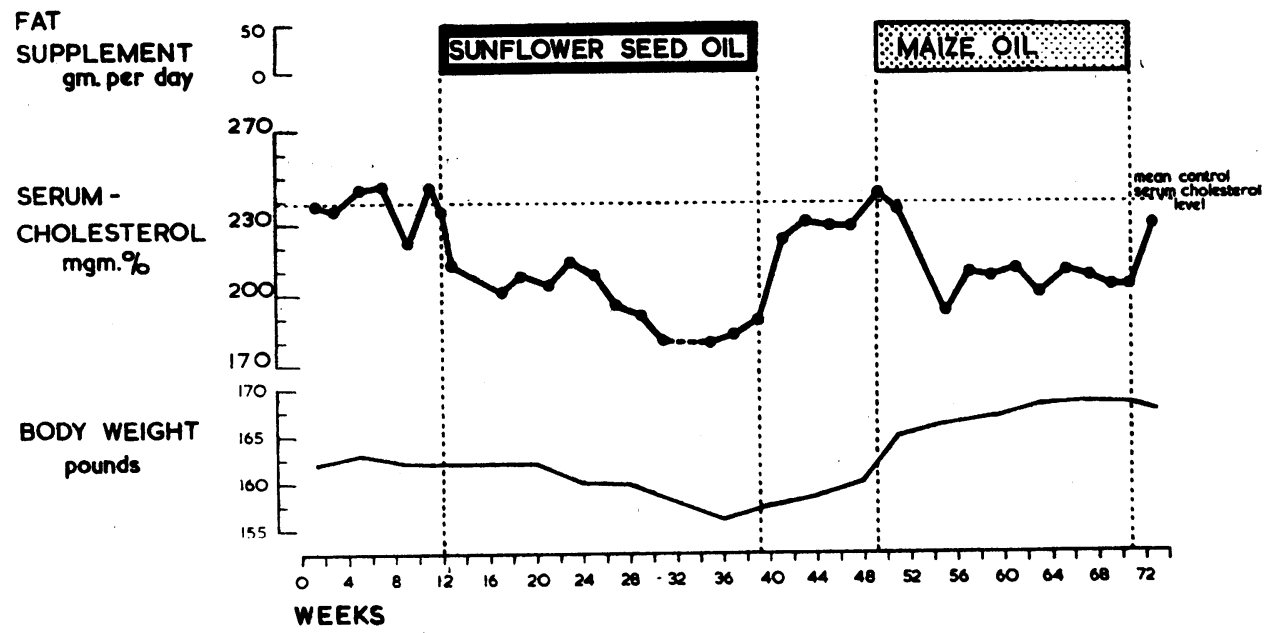

FIG. 4.--European male, 47 years with coronary heart disease, studied as an outpatient. After control periods, $5 \circ \mathrm{g}$. of sunflower seed oil or $50 \mathrm{~g}$. of corn oil were taken as supplements to his ordinary diet, for periods of 27 and 22 weeks respectively. During each fat-supplement period, the serum-cholesterol level was reduced and the fall maintained. Note that these changes in the serum-cholesterol level occurred despite a fall in weight during the sunflowerseed oil period and a gain in weight during the corn oil period. (Each point on the serumcholesterol graph represents the mean of two consecutive readings of the serum-cholesterol level.) (From Gordon and Brock, 1958.)

impaired by heating it under conditions which simulated domestic cooking; it was also shown that when a saturated fat and an unsaturated fat are fed together, the cholesterogenic effect of the former may be abolished (Fig. 3). It was demonstrated in a group of normally active men that the addition of about $50 \mathrm{~g}$. of an unsaturated fat to their usual diet produced a significant fall in their serum-cholesterol levels which could be maintained for as long as the unsaturated fat supplement was consumed (Gordon and Brock, 1958) (Fig. 4). In a group of ro such men, an average fall of $34 \mathrm{mg}$. per $100 \mathrm{ml}$. was maintained for an average period of six months; this fall was of the same order which Hatch et al. (1955) achieved with the use of the almost fat-free rice diet.

Chain Length: During the last three years, workers in many parts of the world have confirmed that dietary fats differ in their effect on the serumcholesterol level. No agreement has been reached, however, on which characteristic of a fat determines its action. While the 'degree of saturation' hypothesis of Ahrens is useful as a general guide, it is not always possible to predict the effect of a fat simply from its iodine value. Thus, Ahrens et al. (1957) themselves noted that the cholesterogenic action of cocoa-butter (iodine value 37 ) is significantly less than that of ordinary butter which has almost the same iodine value. They noted that the component fatty acids of butter have shorter chain-lengths than those of cocoabutter and they have suggested that in addition to its iodine value, the saponification number of a dietary fat (which is an index of the chain-lengths of its component fatty acids) may also play a part in determining its cholesterogenic effect.

Essential Fatty Acids: On the other hand, Kinsell and Sinclair (1957) believe that those unsaturated fats which decrease the serum-cholesterol level do so by virtue of their content of certain specific fatty acids, the so-called ' essential fatty acids.' 'The biological importance of these acids in animals was first described by Burr and Burr in 1929 and they were defined as "a group of unsaturated acids which will bring about a renewal of growth of rats which have reached a plateau on a low-fat diet' (Burr, 1942). There is no direct evidence that the ' essential fatty-acid deficiency ' syndrome of animals has a counterpart in man, nor is there any unanimity of opinion about which fatty acids are ' essential' for animal growth. Only linoleic acid and arachidonic acid appear on all the lists of essential fatty acids; the former is a major constituent of all the vegetable fats with cholesterol-decreasing properties. Any isomeric modification of linoleic acid, however, results in a loss of its activity and it should be noted that in the process of hydrogenation, isomerization as well as saturation of fatty acids occurs. Kinsell and Sinclair postulate that a relative deficiency of essential fatty acids in those consuming saturated fats increases the serum-cholesterol level. Kinsell et al. (1958) have, in fact, shown that 96 per cent. pure linoleic acid can lower the serum-cholesterol level in man, but a control investigation with its non-essential isomers 


\section{CALORIC INTAKE per doy}

SERUM-

CHOLESTEROL $m g m . \%$

\section{BODY WEIGHT pounds}

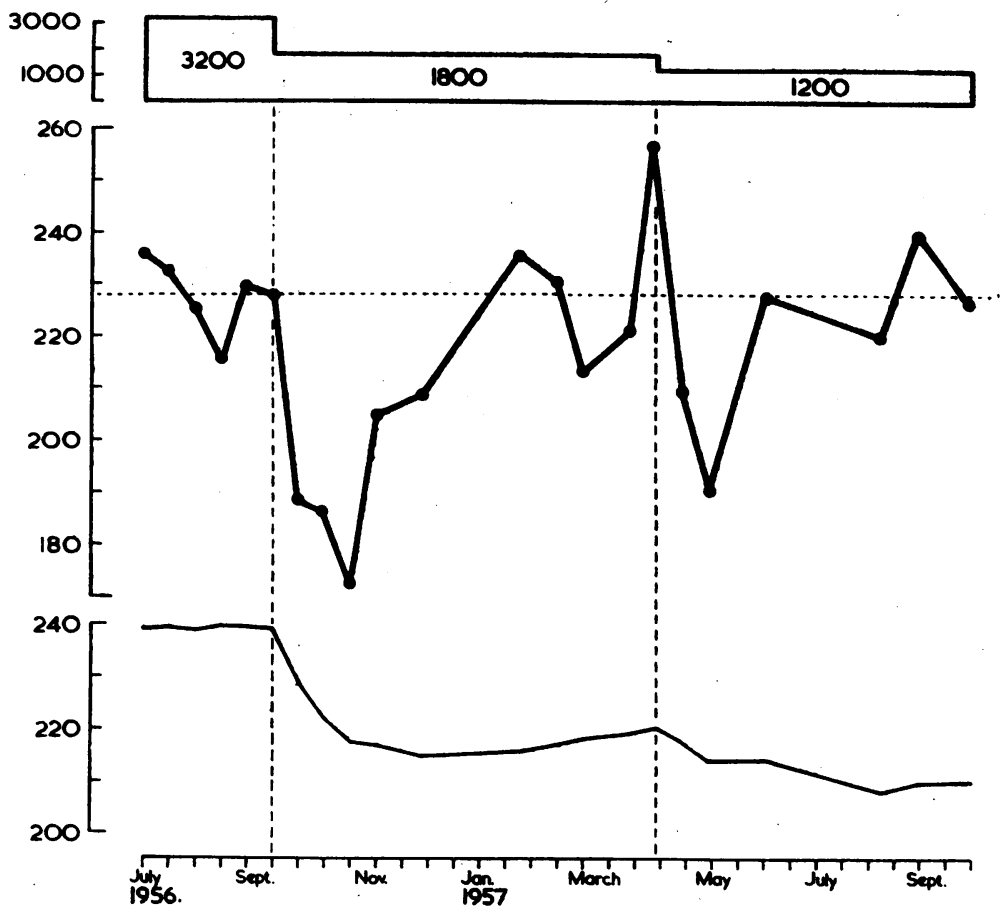

Fig. 5.-Normal European male, 46 years old, studied as an outpatient. Note that on each occasion the dietary calories were decreased there was a prompt loss of weight, which was sustained. At the same time the serum-cholesterol level fell but the fall was not maintained. (Serumcholesterol recorded as in Fig. 4.) (From Gordon and Brock, 1958.) has yet to be reported.

The Unsaponifiable Fraction: In contrast to the above theories, which emphasize the importance of the fatty-acid moiety, Beveridge and his associates in Canada have postulated that much of the activity of a dietary fat is due to its unsaponifiable fraction. The unsaponifiable fraction contains sterols (including sitosterol), hydrocarbons (including squalene and the carotenoids), the vitamins $D, E$ and $K$, a number of waxes and phosphatides, and other unidentified substances. Beveridge et al. (1957a) believe that the activity of the unsaponifiable fraction is due to its sitosterol content; on the basis of a large number of short-term experiments with formula diets, they have claimed that the cholesterol-lowering effect of corn oil can be reproduced by its sitosterol equivalent. However, both Ahrens and his associates (1957) and our group (Gordon et al., 1958) have found that the cholesterol-decreasing effect of corn oil and sunflower-seed oil is unimpaired when they have been rendered very largely free from their unsaponifiable fraction; furthermore, we have been unable to detect any cholesterol-lowering effect when the unsaponifiable fraction of either sunflower-seed oil or pilchard oil is fed alone. Some workers have claimed that crystalline sitosterol effectively lowers the serum-cholesterol level in man. In these studies, most of which were poorly controlled, about $15 \mathrm{~g}$. of sitosterol daily was required to produce an effect: this is equivalent to the sitosterol content of about a litre of corn oil daily. Recently, Riley and Steiner (1957) carried out a carefully controlled study of sitosterol in patients with coronary heart disease; in this trial, doses of 19 to $52.5 \mathrm{~g}$. of sitosterol daily for one to six months produced significant falls in the serum-cholesterol levels in only half of the patients, the overall fall for the group being only 6.6 per cent.

It must be concluded from the above discussion that, while there is no doubt that the consumption of certain unsaturated fats will lower the serumcholesterol level, the factor or factors in these fats which determines their activity is at present unknown.

\section{(c) Calories}

Reducing Diets: Walker et al. (1953) have claimed that caloric balance plays a major role in controlling serum-lipid levels. Their own studies, however, provide little support for this suggestion. Thus, in their 39 subjects who consumed a diet of $r, 250$ calories ( 36 per cent. fat-calories) the average weight loss was 19 pounds in 106 days; during this period, the mean decrease in the serumcholesterol level was $17 \mathrm{mg}$. per $100 \mathrm{ml}$. which is 


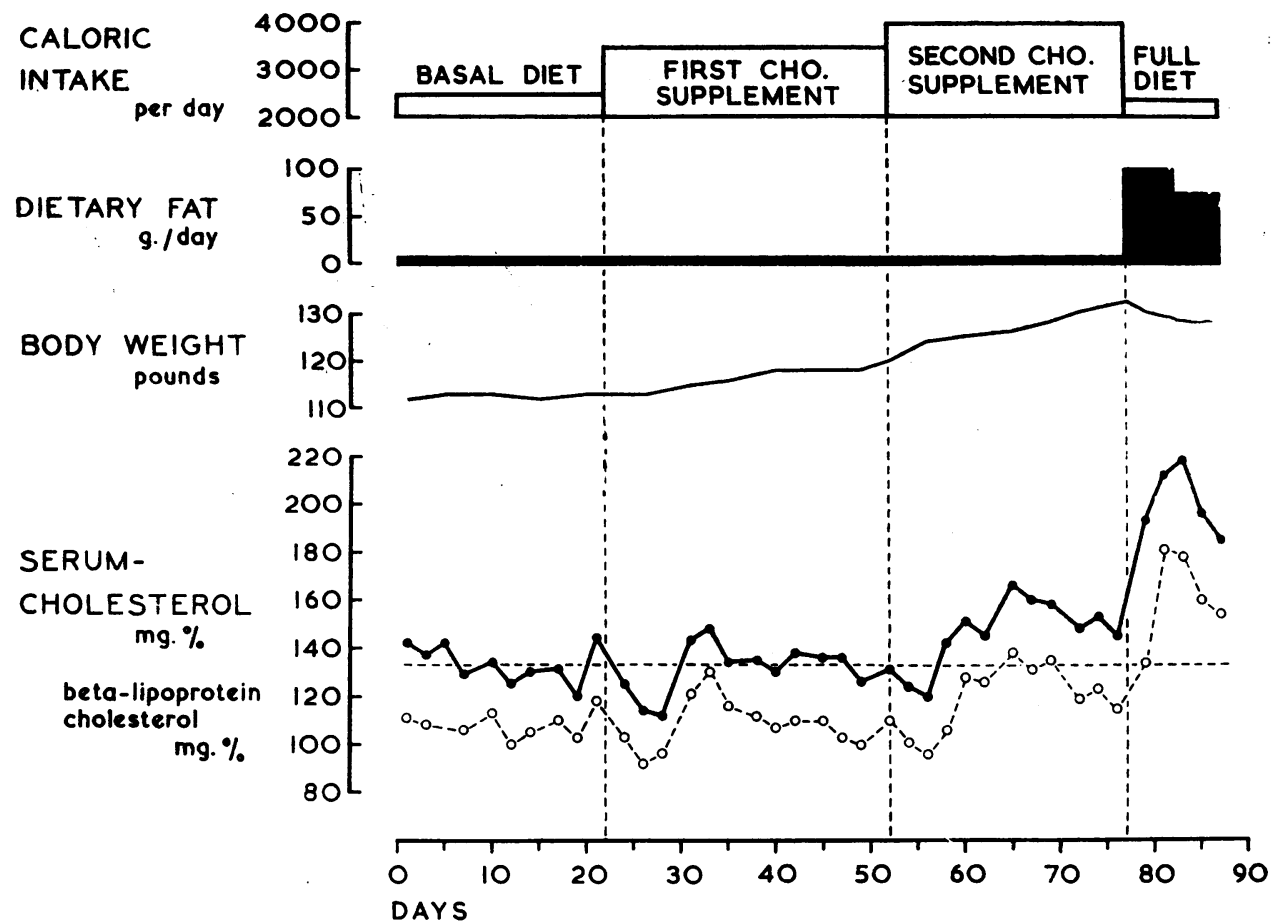

Fig. 6.-Normal Cape coloured male, 45 years old, studied in the metabolism ward. The addition of 1,000 dietary calories, all derived from sucrose, produced a slight weight gain (5 pounds) but no change in the serum-cholesterol level. The addition of a further 500 calories derived from sucrose produced a marked gain in weight ( 12 pounds in 25 days) and a slight increase in the serum-cholesterol level. Despite the marked reduction in the dietary calories, the introduction of animal fat into the diet produced a sharp increase in the serum-cholesterol level.

not statistically significant; in fact, those subjects who lost most weight showed an increase in their serum-cholesterol level. Other workers (e.g. Poindexter and Bruger, 1935) have had inconsistent results from reducing diets, the serumcholesterol level increasing in some subjects and falling in others, while in studies on overweight women, both Young et al. (1953) and Moore et al. (1954) found that weight loss was often associated with an increase in the serumcholesterol level. Our own observations are limited but seem to indicate that rapid weight loss is accompanied by a fall in the serum-cholesterol level which is not sustained; this is illustrated in Fig. 5.

Starvation: The effects of complete starvation on the serum-cholesterol level have not been adequately studied. Partial starvation has been investigated by Keys et al. (1950) in 36 conscientious objectors who lived on a diet of 1570 calories (17 per cent. fat-calories) for six months. The decrease in the serum-cholesterol level was $17 \mathrm{mg}$. per $100 \mathrm{ml}$., which, although small, was statistically significant.

Calorie Excess: There is no regular association of serum-cholesterol levels with body weight. In Minnesota, Keys (1956a) found no significant difference in the serum-cholesterol levels of overweight men and controls. In an inter-racial survey in the Cape Peninsula, in which relative obesity was measured on the basis of skin-fold thickness, a correlation between obesity and serumcholesterol levels was found in Bantu men, but not in Cape Coloured or White men (Keys, 1956b). Anderson et al. (1957) studied this problem experimentally in a group of men in an institution; they found that when caloric increments were introduced into the diet, the serum-cholesterol level increased only during periods of rapid weight gain. Our own observations, of which Fig. 6 is an example, have confirmed this.

\section{(d) Protein}

In controlled feeding experiments on human subjects neither Keys and Anderson (1957) nor we (Gordon et al., 1958) were able to detect any differences in the serum-cholesterol level when low- and high-protein diets were compared. This is in keeping with the epidemiological evidence which shows no correlation between serum- 
cholesterol levels and protein intake in population groups (e.g. Scrimshaw et al., 1957). Recently, however, Olson et al. (1958) claims to have produced a substantial reduction in the serum-cholesterol levels of seven human subjects within a week merely by reducing their protein intake from $100 \mathrm{~g}$. to $25 \mathrm{~g}$. daily. In this experiment total fat, but not the quality of fat, was kept constant and these findings require confirmation before dietary protein can be accorded a significant role in the regulation of the human serum-cholesterol level.

\section{(e) Vitamins}

Pyridoxine: Pyridoxine has been shown to facilitate the conversion of linoleic to arachidonic acid in vivo; hence, Sinclair (1956) suggested that lack of this vitamin, by promoting a relative ' essential fatty acid' deficiency, may play a part in increasing the human serum-cholesterol level. But when Failey (1958) administered about $400 \mathrm{mg}$. of pyridoxine daily (i.e. about roo times the average human requirement) to a series of hospital patients, reductions in the serum-cholesterol level occurred in only some of the subjects and even these were usually trivial.

Nicotinic Acid: Nicotinic acid has been reported to lower the human serum-cholesterol level (Parsons and Flynn, 1957). To produce this effect, very large doses of nicotinic acid must be given (3-6 g. daily) and its biologically active analogue, nicotinamide, is inert is this respect. It is clear, therefore, that the effect of nicotinic acid is not that of a natural food factor and its action is more of pharmacological than nutritional interest.

Cyanocobalamin: In pernicious anaemia and in the anaemias generally, low serum-cholesterol levels occur (Bloor and MacPherson, I9I7) and it is of historical interest to note that before the introduction of liver therapy, cases of pernicious anaemia were often treated with cholesterol (Campbell, 1925). Muller (1930) found that when an active haemopoietic preparation (liver, gastric juice, etc.) was given to cases of pernicious anaemia in relapse, the serum-cholesterol level rose sharply with the reticulocytes before there was an increase in the erythrocytes or haemoglobin. In two healthy men, liver extracts were without effect on the serum-cholesterol level.

Ascorbic Acid: Apart from a report by Anderson et al. (1957) that the cholesterol-decreasing effect of safflower oil is augmented by ascorbic acid, the effect of this vitamin on the human serumcholesterol level is unknown.

Tocopherol: It has been suggested that the cholesterol-decreasing effect of the highly unsaturated fats may be due to their vitamin $\mathrm{E}$ content (le Riche, 1956). This cannot, however, explain the efficacy of the marine oils, many of which contain very little tocopherol (Lange, r950). Neither Keys et al. (1957) nor Beveridge et al. (1957) produced any effect with 100 or $200 \mathrm{mg}$. of alpha-tocopherol daily and it must be concluded that this vitamin has no direct action on the serumcholesterol level. Nevertheless, by virtue of its function as a natural antoxidant, it maintains the stability of vegetable oils and indirectly promotes their cholesterol-decreasing effect.

\section{(f) Lipotropic Agents}

- The success in the mobilization of lipids from the liver in animals and man suggested to me the possibility that the lipotropic agents might affect blood cholesterol and cholesterol esters and phospholipid levels ....'(Herrmann, 1947). This somewhat specious rationale has been the basis of large numbers of investigations into the effect of lipotropic substances on the serum-cholesterol level. Many of these investigations have been poorly conceived and their results are generally unacceptable. To date, the lipotropic agents have not been shown substantially to influence the serum-cholesterol level.

\section{(g) Fibre}

The average Bantu diet in Southern Africa is relatively rich in crude fibre; Walker and Bersohn (1957) have suggested that this may increase the endogenous faecal fat excretion and indirectly modify the serum lipid pattern of this race. Feeding experiments in this department have shown, however, that only when the dietary fibre content is artificially increased to unnatural levels does a modest increase in faecal fat occur with a small reduction in the serum-cholesterol level (Gordon, 1959). There is no evidence that the crude-fibre content of ordinary diets affects the serumcholesterol level.

\section{(h) Minerals}

In experimental animals, the effects of several trace elements on the serum-cholesterol level have been studied, but in man interest has mainly been focussed on magnesium. In Johannesburg, Bersohn and Oelofse (1957) found that Bantu have higher serum-magnesium levels than age-matched Whites; in the latter, the serum-magnesium and serum-cholesterol levels were inversely related though not in strictly linear fashion. Bersohn (1958) has suggested that magnesium may have a heparin-like action in lowering serum-lipid levels, and Malkiel-Shapiro et al. (1956) have claimed that weekly injections of $\mathrm{I} \mathrm{ml}$. of 50 per cent. magnesium sulphate improves the abnormal serumlipid levels of patients with coronary heart disease. This investigation, however, was poorly con- 
trolled and Sandler and McGregor (1958) were unable to confirm its findings.

\section{(i) Alcohol}

During the course of a sociological study of a series of elderly Londoners living at home on ordinary diets, Hobson et al. (1953) found that life-long teetotallers had higher serum-cholesterol levels than those who habitually consumed at least 5 pints of beer daily. In an inter-racial survey (Bronte-Stewart, 1957) it was shown that heavy alcohol consumption was associated with lower serum-cholesterol levels only in the poorer socioeconomic groups. It was suggested that this association could result from a lower available income for the more expensive foods rich in animal fats.

\section{Summary}

I. Each individual has a ' characteristic' serumcholesterol level which under normal living conditions is fairly constant but around which marked fluctuations may occur from week to week.

2. Genetic and hormonal factors and the individual's age play a part in determining his serum-cholesterol level.

3. Among the environmental factors which influence the serum-cholesterol level, the role of the dietary fat is pre-eminent; in this respect, the quality of the dietary fat is more important than its quantity.

\section{BIBLIOGRAPHY}

ADLERSBERG, D. (195I), Amer. F. Med., I1, 600.

ADLERSBERG, D., SCHAEFER, L. E., STEINBERG, A. G., and CHUN-I. WANG (1957), F. Amer. med. Ass., 162, 619.

AHRENS, E. H. Jnr., HIRSCH, J., INSULL, W., TSALTAS, T. T., BLOMSTRAND, R., and PETERSON, M. L. (1957), Lancet, $i, 943$.

ANDERSON, J. T., and KEYS, A. (1953), Fed. Proc., 12, 169.

ANDERSON, J. T., LAWLER, A., and KEYS, A. (1957), $\mathcal{f}$. clin. Invest., 36, 81 .

ANDERSON, J. T., GRANDE, F., and KEYS, A. (1957), Fed. Proc., 16, 380.

ANITSCHKOW, N. (I933), 'Arteriosclerosis,' E. V. Cowdry, MacMillan, N.Y. Chapter ro.

BARR, D. P. (1953), Circulation, 8, 641.

BEISCHER, D. E. (1955), F. Aviat. Med., 27, 260.

BERSOHN, I. (1958), Med. Proc., 4, 62.

BERSOHN, I., and OELOFSE, P. J. (1957), Lancet, i, 1020.

BERSOHN, I., and WAYBURNE, S. (1956), Amer. F. clin. Nutr., 4,117 .

BEVERIDGE, J. M. R., CONNELL, W. F., and MAYER, G. A. (1957(a)), Fed. Proc., I6, I I.

BEVERIDGE, J. M. R., CONNELL, W. F., and MAYER, G. A. (1957(b)), Canad. Э. Biochem. Physiol., 35, 257.

BIÖRCK, G., BLOMGUIST, G., and SIEVERS, J. (1957), Acta. med. scand., 156, 493.

BLOOR, W. R., and MACPHERSON, D. J. (1917), f. biol. Chem., 31, 79.

BOYD, E. M. (1935), Ibid., 110, 6r.

BRONTE-STEWART, B. (1956), Brit. med. F., ii, 659.

BRONTE-STEWART, B. (1957), Nutrit. (Lond.), 2, 60.

BRONTE-STEWART, B., KEYS, A., and BROCK, J. F. (1955a), Lancet, ii, 1103 .

BRONTE-STEWART, B., MOODIE, A. D., ANTONIS, A., EALES, L., and BROCK, J. F. (1955b), S. Afr. med. $\mathcal{F}$.'

BRONTE-STEWART, B., ANTONIS, A., EALES, L., and BROCK, J. F. (1956), Lancet, $i, 521$.

BRUNNER, D., and LOBL, K. (I957), Ibid., i, 1300.

BURR, G. O. (1942), Fed. Proc., 1, 224.
BURR, G. O., and BURR, M. M. (1929), Ұ. biol. Chem., 82, 345. CAMPBELL, J. M. H. (1925), Quart F. Med., 18, 393.

CURRIE, A. N. (1924), Brit. F. exp. Path., 5, 293.

DONATH, W. F., FISHCER, I. A., v.d. MEULEN-VAN EYSBERGEN, 'H. C., and DE WIJN, J. F. (1953), Voeding, I4, 153 .

EILERT, M. L. (1953), Metabolism, 2, 137.

FAILEY, R. B. Jnr. (1958), Circulation Res., 6, 203.

GERTLER, M. M., and WHITE, P. D. (1054), ' Coronary Heart Disease in Young Adults. A Multidisciplinary Study,' Harvard University Press, Cambridge, Mass.

GILDEA, E. F., KAHN, E., and MAN, E. B. (1936), Amer. F. Psychiat., 92, 1247.

GOFMAN, J. W., LINDGREN, F. T., STRISOWER, B., DE LALLA, O., GLAZIER, F., and TAMPLIN, A. (I955),

GOPALAN, C., and RAMANATHAN, K. S. (1956), Lancet, ii, 1212. GORDON, H. (1959), in the press.

GORDON, H., and BROCK, J. F. (1958), S. Afr. med. F., 32, 397.

GORDON, H., LEWIS, B., EALES, L., and BROCK, J. F. (1957), Lancet, ii, 1299.

GORDON, H., WILKENS, J., and BROCK, J. F. (1958), S. Afr. med. F., 32, 549 .

GROEN, I. TIIANG, B. K., KAMMINGA, C. E., and WILLEBRANDS, A. F. (1952), Voeding, 13, 556.

HARDINGE, M. G., and STARE, F. J. (1954), Amer. F. clin. Nutr., 2, 83.

HATCH, F. T., ABELL, L. L., and KENDALL, F. E. (1955), Amer. $\mathscr{F}$. Med., 19, 48 .

HERRMANN, G. R. (1947), Exp. Med. Surg., 5, 149.

HOBSON, W., JORDAN, A., and ROSEMAN, C. (1953), Lancet, ii, 961 .

KEMPNER, W. (1949), Ann. intern. Med., 31, 821.

KEYS, A. (1952), Voeding, 13, 539.

KEYS, A. (r956(a)), F. chron. Dis., 4, 364.

KEYS, A. (1956(b)), ' World Trends in Cardiology, Vol. I, Cardiovascular Epidemiology,' A. Keys and P. D. White, HoeberHarper, N.Y.

KEYS, A. (1957), F. Amer. med. Ass., 164, 1912.

KEYS, A., ANDERSON, J. T., and GRANDE, F. (1957), Lance i, 66 .

KEYS, A., ANDERSON, J. T., and MICKLESEN, O. (1956) Science, 123, 29.

KEYS, A., ANDERSON, J. T., MICKELSEN, O., ADELSON, J. F., and FIDANZA, F. (1956), F. Nutr., 59, 39.

KEYS, A., BROZEK, J., HENSCHEL, A., MICKELSEN, O. and TAYLOR, H. L.' (1950), 'The Biology of Human Starvation,' Univ. Minnesota Press, Minneapolis. Vol. I, chapter 22.

KEYS, A., and KEYS, M. H. (1954), Brit. F. Nutr., 8, 138.

KEYS, A., KIMURA, N., KUSUKAWA, A., BRONTESTEWART, B., LARSEN, N. P., and KEYS, M. H. (1958), Ann intern. Med., 48, 83.

KEYS, A., MICKLESEN, O., MILLER, E. V. O., and CHAPMAN, C. B. (1950), Science, 112, 79.

KEYS, A., VIVANCO, F., RODRIOUEZ MINON, J. L., KEYS M. H., and CASTRO-MENDOZA, H. (1954), Metabolism, 3, 195 .

KEYS, A., et al. (1956), F. clin. Invest., 35, I 173.

KINSELL, L. W., MICHAELS, G. D., FRISKEY, R. W., and SPLITTER, S. (I958), Lancet, i, 334.

KINSELL, L. W., PARTRIDGE, J., BOLING, L. A., MAGEN S., and MICHAELS, G. D. (1952), F. clin. Endocr. and Metab. 12, 909 .

KINSELL, L. W., and SINCLAIR, H. M. (I957), Lancet, i, 883

KYLE, L. H., HESS, W. C., and WALSH, W. P. (1952), f. Lab. clin. Med., 39, 605 .

LANGE, W. (1950), F. Amer. Ocl. chem. Soc., 27, 414.

LAWRY, E. Y., MANN, G. V., PETERSON, A., WYSOCKI, A. P., O'CÖNNELL, R., and STARE, F. J. (1957), Amer. $\mathcal{F}$. Med., 22, 605 .

le RICHE, H. (1956), Canad. med. Ass. F., 74, 644.

LINDHOLM, H. (1956), Scand. F. clin. Lab. Invest., 8, supp. 23.

McEACHERN, J. M., and GILMOUR, C. R. (1932), Canad. med. Ass. F., 26, 158.

McQUARRIE, I., and STOESSER, A. V. (1932), Proc. Soc. $\operatorname{exp.}$ Biol. (N.Y.), 29, $128 \mathrm{I}$.

MALKIEL-SHAPIRO, B., BERSOHN, I., and TERNER, P. E. (1956), Med. Proc., 2, 455.

MANN, G. V., NICOL, B. M., and STARE, F. J. (1955), Brit. med. $尹$., ii, 1008 .

MANN, G. V., TEEL, K., HAYES, O., McNALLY, A., and BRUNO, D. (1955), New Engl. F. Med., 253, 349.

Bibliography continued on page 217 
particularly if they lead to sustained reduction of the serum cholesterol. This tentative conclusion does not imply that unsuitable diets are the only, or even the most important, cause of coronary heart disease; it implies only that dietary modification can improve life expectation in people at risk.' A rational basis for this treatment has been provided in the demonstration that certain unsaturated oils increase the excretion of cholesterol as cholic acid several-fold (Lewis, 1958). It is therefore suggested that people at risk should reduce their total fat to something of the order of 25 to 30 per cent. of calories and should substitute to a reasonable extent certain unsaturated oils of vegetable and marine origin for at least a part of their saturated fat intake; i.e. animal fats and any fats which have been artificially hydrogenated. Such a diet can with a little trouble be made palatable and free from nuisance value to the patient and his family (Gordon and Brock, 1958).

It is recognized that the diet consumed by privileged western communities who have a high incidence of ischaemic heart disease differs in many respects, other than in quality and quantity of fat, from the diets of uhderprivileged communities in whom the disease is uncommon.
Any of these other differences might be contributory, but the only difference which has yet been shown to have a rational causative basis, through its effect on serum lipid levels, is that which underlies the recommendation for dietary modification of quantity and quality of fat. In particular carbohydrates, proteins and cellulose have comparatively little effect (Gordon et al., 1958).

It should be emphasized that it is at present just as likely that the beneficial effect of this type of dietary modification is exerted through the prevention of thrombotic occlusive episodes as through its effect on serum lipid levels. It is further emphasized that because of the uncertainties and apparent conflicts which underlie the whole story, the time is not yet ripe for any general advice to populations at large on the consumption of fats in relation to atherogenesis in general. Action on an incompletely proven dietary theory is, however, justifiable in the case of myocardial infarction since it is a serious disease, with increasing prevalence. Dietetics has been a rich field for quackery and a hypothesis, however responsible, must not be dressed up to look like a fact. To-day's remedies may be replaced to-morrow by new knowledge.
MESSINGER, W. J., POROSOWSKA, Y., and STEELE, J. M. (1950), Arch. intern. Med., 86, I89.

MULLER, G. L. (1930), Amer. F. med. Sci., 179, 316.

OLIVER, M. F., and BOYD, G. S. (1953), Clin. Sci., 12, 217.

OLSON, R. E., VESTER, J. W., GURSEY, D., DAVIS, N., and LONGMÁN, D. (1958), Amer. F. clin. Nutr., 6, 3 10.

ORMA, E., KARVONEN, M., KEYS, A., and BROZEK, J. (1958), Fed. Proc., 17, 120.

PARSONS, W. B. Jnr., and FLYNN, J. H. (1957), Circulation, I6, 499 .

POINDEXTER, C., and BRUGER, M. (1935), Arch. intern. Med., 56,884 .

POMERAN7E, J., GOALWIN, A., and SLOBODY, L. B. (1957), Circulation, 16, 481 .

RALLI, E. P., KUHL, W. J. Jnr., GERSHBERG, H., BECK, E. M., STREET, E. R., and LAKEN, B. (1956), Metabolism, 5, 270.

RILEY, F. P., and STEINER, A. (1957), Circulation, 16, 723.

ROSENMAN, R. H., and FRIEDMAN, M. (1957), Ibid., 16, 93 I.

SANDLER, A., and MCGREGOR, M. (1958), S. Afr. med. $\mathcal{F}$., 32,697 .

SCHAEFER, L. E., ADLERSBERG, D., and STE்INBERG, A. G. (1958), Circulation, 17, 537.
SCRIMSHAW, N. S., BALSAM, A., and ARROGAVE, G. (1957), Amer. F. clin. Nutr., 5, 629 .

SCRIMSHAW, N. S., TRULSON, M., TEJADA, C., HEGSTED, D. M., and STARE, F. J. (1957), Circulation, 15, 805 .

SINCLAIR, H. M. (1956), Lancet, i, 387.

SPERRY, W. E. (1937), f. biol. Chem., $117,391$.

STARKE, H. (1950), Amer. F. Med., 9, 494.

TAYLOR, H. L., ANDERSON, J. T., and KEYS, A. (1957), Proc. Soc. exp. Biol. (N.Y.), 95, 383.

TOOR, M., KATCHALSKY, A., AGMON, J., and ALLABOUF, D. (1957), Lancet, i, 1270.

TURNER, K. B., and STEINER, A. (1939), f. clin. Invest., 18, 45. WALKER, A. R. P., and ARVIDSON, V. B. (1954), Ibid., 33, 1358.

WALKER, A. R. P., and BERSOHN, I. (1957), S. Afr. med. F., suppl. 'Medicine in South Africa,' p. 106.

WALKER, W. J., LAWRY, E. Y., LOVE, D. E., MANN, G. V., LEVINE, S. A., and STARE, F. J. (1953), Amer. F. Med., 14, 654 .

WERTLAKE, P. T., WILCOX, A. A., HALEY, M. I., and PETERSON, J. E. (1958), Proc. Soc. exp. Biol. (N.Y.).

WILKINSON, C. F. Jnr., HAND, E. A., and FLIEGELMAN, M. T. (1948), Ann. intern. Med., 29, 676.

YOUNG, C. M., RINGLER, I., and GREER, B. J. (1953), f. Amer. diet. Ass., 29, 890. 